\section{Pulmonary vascular reactivity in severe pulmonary hypertension associated with mixed connective tissue disease}

Philippe Jolliet, Jean-Benoît Thorens, Jean-Claude Chevrolet

\begin{abstract}
Pulmonary vascular reactivity tests were performed in a young woman with mixed connective tissue disease and severe pulmonary hypertension. Vasoreactivity was documented in response to intravenous prostacyclin $\left(\mathbf{P G I}_{2}\right)$, oral nifedipine, and inhaled nitric oxide, with quantitative differences. Nitric oxide produced a moderate lowering of pulmonary arterial pressure and resistance without any deleterious systemic effect. The use of nitric oxide in testing for pulmonary vasoreactivity merits further evaluation. (Thorax 1995;50:96-97)
\end{abstract}

Keywords: pulmonary vascular reactivity, pulmonary hypertension, mixed connective tissue disease, nitric

Reprint requests to: Dr P Jolliet, Soins Intensifs de Médecine, Hôpital 24, Rue Micheli-du-Crest, 1211 Genève 14, 1211 Genève

Received 30 September 1993

1993

Returned to authors

14 December 1993

4 January 1994

Accepted for publication

6 January 1994 oxide.

Pulmonary hypertension in mixed connective tissue disease is often resistant to immunosuppressive agents. ${ }^{12}$ Treatment with vasodilators might be the only option to improve survival, ${ }^{3}$ and they have been shown to be effective in mixed connective tissue disease. ${ }^{4}$ The prerequisite to initiating treatment is that vasoreactivity must be preserved. ${ }^{3}$ However, testing with vasodilators that have systemic effects can produce severe complications. ${ }^{5}$ Nitric oxide could represent an alternative as it is devoid of these effects when inhaled. This case report documents the use of nitric oxide for such a purpose in a patient with mixed connective tissue disease.

\section{Case report}

A 31 year old woman presented with asthenia, weight loss $(5 \mathrm{~kg})$, dryness of mouth and eyes, dysphagia, Raynaud's phenomenon, lower limb myalgias, progressive dyspnoea, and retrosternal pain.

On physical examination she was afebrile, heart rate $84 / \mathrm{min}$, blood pressure $130 /$ $80 \mathrm{~mm} \mathrm{Hg}$. There was salivary gland hypertrophy, no clubbing, multiple, bilateral, lymphadenopathy, no inspiratory crackles with an enlarged, non-tender liver and spleen. Laboratory examination showed erythrocyte sedimentation rate of $100 \mathrm{~mm} / \mathrm{h}$, protein $103 \mathrm{~g} / \mathrm{l}$, IgG $55 \cdot 7 \mathrm{~g} / 1$ (normal $7 \cdot 5-16 \cdot 2 \mathrm{~g} / 1$ ), no paraproteinaemia, AST/ALT 71/54 IU/1 (<32/36), lactate dehydrogenase $686 \mathrm{IU} / 1 \quad(<412)$. Rheumatoid factor, antinuclear and antiribonucleoprotein antibodies were positive (titres of 1:320, 1:40000 and 1:1024, respectively); anti-DNA, anti-Jo1, antiScl-70, antisalivary gland, anti-Sm-protein, and antineutrophil cytoplasmic antibodies were negative. The chest radiograph showed cardiomegaly with normal lung parenchyma. Electrocardiogram showed sinus rhythm, right axis deviation and T wave inversion in leads V1-V4. The isotopic ventilation/perfusion lung scan was normal; arterial blood gases (room air) were $\mathrm{pH} 7 \cdot 44 / \mathrm{PaO}_{2} \quad 9 \cdot 67 \mathrm{kPa} / \mathrm{PaCO}_{2} \quad 4.0 \mathrm{kPa} /$ $\mathrm{SaO}_{2}$ 95\%. Pulmonary function tests were normal apart from the carbon monoxide transfer factor (TLCO) $5.3 \mathrm{mmol} / \mathrm{kPa} / \mathrm{min}$ (predicted $8 \cdot 6)$. Cervical lymph node biopsy showed nonspecific hyperplasia.

Mixed connective tissue disease was diagnosed. Vasodilator tests were performed. Pulmonary (PAP) and systemic (PAS) blood pressures were continuously monitored and graphically recorded. Pulmonary (PVR) and systemic (SVR) vascular resistance were com-

Results of vasodilator tests

\begin{tabular}{|c|c|c|c|c|c|c|}
\hline & \multicolumn{2}{|c|}{ Prostacyclin } & \multicolumn{2}{|c|}{ Nifedipine } & \multicolumn{2}{|c|}{ Nitric oxide } \\
\hline & Baseline & Max effect (\%) & Baseline & Max effect (\%) & Baseline & Max effect (\%) \\
\hline $\begin{array}{l}\text { Haemodynamic values: } \\
\text { Heart rate }(\mathrm{n} / \mathrm{min}) \\
\text { Cardiac output }(1 / \mathrm{min})\end{array}$ & $\begin{array}{c}73 \\
6 \cdot 2\end{array}$ & $\begin{array}{l}75 \\
10 \cdot 0\end{array}$ & $\begin{array}{l}71 \\
6 \cdot 3\end{array}$ & $\begin{array}{l}84 \\
10 \cdot 6\end{array}$ & $\begin{array}{l}84 \\
7 \cdot 7\end{array}$ & $\begin{array}{l}83 \\
7.8\end{array}$ \\
\hline $\begin{array}{l}\text { SAP }(\mathrm{mm} \mathrm{Hg}) \\
\text { systolic } \\
\text { diastolic } \\
\text { mean } \\
\text { mean }\end{array}$ & $\begin{array}{r}116 \\
68 \\
84\end{array}$ & $\begin{array}{r}108 \\
61 \\
77\end{array}$ & $\begin{array}{r}109 \\
61 \\
76\end{array}$ & $\begin{array}{l}94 \\
51 \\
63\end{array}$ & $\begin{array}{r}122 \\
79 \\
85\end{array}$ & $\begin{array}{r}120 \\
68 \\
81\end{array}$ \\
\hline $\begin{array}{l}\text { PAP }(\text { mm Hg) } \\
\text { systolic } \\
\text { diastolic } \\
\text { mean } \\
\text { SVR (dyn.s.cm-5) } \\
\text { PVR (dyn.s.cm }{ }^{-5} \text { ) }\end{array}$ & $\begin{array}{r}65 \\
22 \\
37 \\
1045 \\
412\end{array}$ & $\begin{array}{l}55 \\
18 \\
31(16 \cdot 2) \\
576 \\
208(49 \cdot 5)\end{array}$ & $\begin{array}{r}42 \\
19 \\
28 \\
926 \\
215\end{array}$ & $\begin{array}{l}37 \\
17 \\
25(10) \\
465 \\
172(20)\end{array}$ & $\begin{array}{r}55 \\
26 \\
37 \\
851 \\
322\end{array}$ & $\begin{array}{l}44 \\
23 \\
29(21 \cdot 2) \\
810 \\
276(14 \cdot 2)\end{array}$ \\
\hline $\begin{array}{l}\text { Arterial blood gases (room air): } \\
\mathrm{pH} \\
\mathrm{PacO}_{2}(\mathrm{kPa}) \\
\mathrm{PaO}_{2}(\mathrm{kPa}) \\
\mathrm{SaO}_{2}(\%)\end{array}$ & $\begin{array}{l}7.43 \\
3.6 \\
11.7 \\
97\end{array}$ & $\begin{array}{l}7 \cdot 44 \\
3 \cdot 2 \\
12 \cdot 8 \\
97\end{array}$ & $\begin{array}{l}7 \cdot 45 \\
3 \cdot 2 \\
13 \cdot 8 \\
98\end{array}$ & $\begin{array}{l}7 \cdot 45 \\
3 \cdot 6 \\
11 \cdot 0 \\
97\end{array}$ & $\begin{array}{l}7 \cdot 45 \\
3 \cdot 5 \\
13 \cdot 3 \\
98\end{array}$ & $\begin{array}{l}7 \cdot 45 \\
3 \cdot 6 \\
10 \cdot 2 \\
96\end{array}$ \\
\hline
\end{tabular}

Max effect = maximum effect obtained with the drug tested expressed as $(\%)$ decrease for PVR and PAPmean; SAP = systemic arterial pressure; PAP $=$ pulmonary arterial pressure; $\mathrm{SVR}=$ systemic vascular resistance; $\mathrm{PVR}=$ pulmonary vascular resistance. 


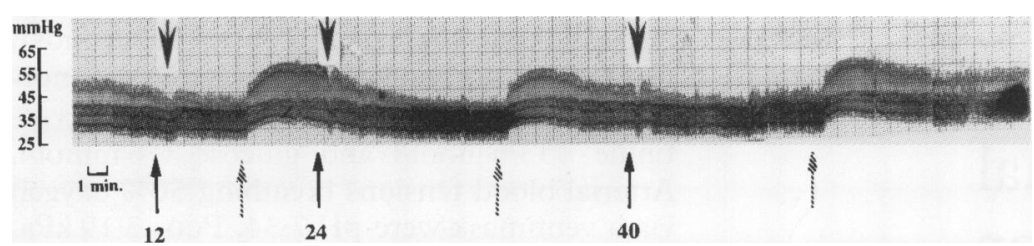

Graphic reconding of pulmonary artery pressure during nitric oxide inhalation. Lower black and striped arrows indicate start and stop, respectively, of nitric oxide inhalation. Nitric oxide concentration (ppm) is indicated in bold numbers. Upper arrows show the initial drop and rebound occurring approximately 30 seconds after the beginning of inhalation. Tracing speed $5 \mathrm{~mm} / \mathrm{min}$.

puted by standard equations. The response was considered positive if mean PAP (PAPm) and/ or PVR decreased by $\geqslant 20 \%$ of baseline. A prostacyclin ( $\mathrm{PGI}_{2}$, Flolan, Wellcome) infusion, $1 \mathrm{ng} / \mathrm{kg} / \mathrm{min}$, was initiated and increased by increments of $1 \mathrm{ng} / \mathrm{kg} / \mathrm{min}$. At $6 \mathrm{ng} / \mathrm{kg} / \mathrm{min}$ the test was stopped (table). The next day oral nifedipine was given. After an initial dose of $10 \mathrm{mg}$, a dose of $20 \mathrm{mg}$ was administered hourly. After a cumulative dose of $50 \mathrm{mg}$ nausea and symptomatic hypotension occurred. Upon return to baseline conditions nitric oxide was administered. The patient was equipped with a noseclip and a tight-fitting mouthpiece connected to a one-way Hans-Rudolf pneumatic valve. A pneumotachograph (Fleisch No. 8) measured total minute ventilation. Nitric oxide was delivered for five minutes at $12 \mathrm{ppm}$, then for two 10-minute periods each at 24 and $40 \mathrm{ppm}$. Maximum effect occurred at $24 \mathrm{ppm}$, without systemic effects (table). PAP decreased within seconds of starting nitric oxide, while rebound followed its cessation (figure).

A single bolus injection of cyclophosphamide $(1000 \mathrm{mg}$ ), and methylprednisolone $250 \mathrm{mg}$ twice daily for three days, were administered. The patient was discharged on oral prednisone $60 \mathrm{mg} /$ day and nifedipine, $20 \mathrm{mg}$ three times daily.

\section{Discussion}

Vasoreactivity was present with all three vasodilators with quantitative differences. $\mathrm{PGI}_{2}$ produced larger decreases in PAPm and PVR than nifedipine (table). However, the baseline values were much lower for nifedipine than for $\mathrm{PGI}_{2}$. The short half-life of $\mathrm{PGI}_{2}$ (1-2 minutes) should preclude any residual effect of the drug 24 hours later. However, we have recently documented major spontaneous variations in PVR (up to $32 \%$ ) in patients with chronic pulmonary hypertension, during 72 hour measurements. ${ }^{6}$ This could account for the differences observed in our patient. Nitric oxide decreased PVR by approximately $50 \%$ in patients with chronic pulmonary hypertension at an inspired concentration of $40 \mathrm{ppm}^{7}$ Using the same concentration we observed a much smaller decrease (14\%), but the baseline PVR in our patient was much lower. ${ }^{7}$

The figure shows that, with all concentrations used, a transient drop in PAP occurred less than 30 seconds after the start of inhalation, followed by a rebound to baseline values and a slow decrease. This could be due to a reflex vasoconstriction compensating for the initial vasodilating effect of nitric oxide, but subsequently overridden by it. Furthermore, seconds after nitric oxide was discontinued a significant rebound was witnesseed. This could stem from pulmonary vascular hyperreactivity, as in systemic hypertension, ${ }^{8}$ increased circulating catecholamines, or intracellular downregulation to the effects of nitric oxide. ${ }^{9}$ No such overshoot occurred after $\mathrm{PGI}_{2}$ or nifedipine.

In conclusion, pulmonary vascular reactivity to nitric oxide in mixed connective tissue disease was documented without adverse systemic effects. Thus, even though only those vasodilators that also exhibit these side effects can be used for long term therapy at present, nitric oxide could represent a useful and safer test agent for vasoreactivity and should be studied further. The overshoot in PAP after discontinuation of nitric oxide merits a note of caution.

1 Dahl M, Chalmers A, Wade J, Calverley D, Munt B. Ten year survival of a patient with advanced pulmonary hypertension and mixed connective 作

2 Bennett RM. Mixed connective tissue disease and other overlap syndromes. In: Kelly WN, Harris ED, Ruddy S, Sledge CB, eds. Textbook of rheumatology. 3rd edn. Philadelphia: WB Saunders, 1989: 1147-65.

3 Rich S, Kaufmann E, Levy PS. The effect of high doses of calcium-channel blockers on survival in primary pulmonary hypertension. $N$ Engl f Med 1992; 327:76-81.

4 Alpert MA, Pressly TA, Mukerji V, Lambert CR, Mukerii B, Panayiotou $\mathrm{H}$, et al. Acute and long-term effects of nifedipine on pulmonary and systemic hemodynamics in patients with pulmonary hypertension associated with patients with pulmonary hypertension associated with
diffuse systemic sclerosis, the CREST syndrome and mixed connective tissue disease. Am $\mathcal{f}$ Cardiol 1991;68:1687-91.

5 Partanen J, Nieminen M, Loumanmäki K. Death in a patient with primary pulmonary hypertension after $20 \mathrm{mg}$ of nifedipine. N Engl f Med 1993;329:812.

6 Chevrolet JC, Schmid F. "Spontaneous" variability of pulmonary haemodynamics during vasodilator tests in pulmonary precapillary hypertension. Eur F Int Med 1992;3: 305-17.

7 Pepke-Zaba J, Higenbottam TW, Dinh-Xuan AT, Stone D, Walwork J. Inhaled nitric oxide as a cause of selective pulmonary vasodilatation in pulmonary hypertension. pulmonary vasodilatatio

8 Fiorentini C, Barbier P, Galli C, Loaldi A, Tamborini G, Tosi E, et al. Pulmonary vascular overreactivity in systemic hypertension. Hypertension 1985;7:995-1002.

9 Moncada S, Palmer RMJ, Higgs EA. Nitric oxide: physiology, pathophysiology, and pharmacology. Pharmacol Rev 1991; 43:109-42. 